\title{
PENGGUNAAN TEKNOLOGI INFORMASI KOMUNIKASI \\ DALAM MANAJEMEN ASI BAGI IBU BEKERJA GUNA MENJAGA KETAHANAN KELUARGA \\ (Studi Pada Anggota Grup Facebook Asosiasi Ibu Menyusui Indonesia)
}

\author{
Valentina Siwi Saridewi \\ Lembaga Ketahanan Nasional Republik Indonesia \\ Email: valentinasiwisaridewi@lemhannas.go.id \\ Armaidy Armawi \\ Fakultas Filsafat Universitas Gadjah Mada \\ Djoko Soerjo \\ Fakultas Ilmu Budaya Universitas Gadjah Mada
}

\begin{abstract}
The research objective was to described the use of information communication technology (ICT) in the breastmilk management that conducted by a working mother who actively feeding to met the needs of breastfeeding for 6 months in order to maintained the family resilience.

Research used qualitative method in order to gathered main data and the result of simple quantitative method as supporting data.

The results showed that the use of ICT in the breastmilk management as a tool to obtained supporting information that required by informants in implementing the breastmilk management. There was description of the relationship between ICT in maintain the family resilience. Informations and motivations that necessary for informant obtained through the use of ICT.
\end{abstract}

Keywords : Information Communication Technology, Breastmilk Management, Family Resilience

\begin{abstract}
ABSTRAK
Tujuan penelitian ini adalah untuk menggambarkan penggunaan Teknologi Informasi Komunikasi (TIK) dalam manajemen Air Susu Ibu (ASI) yang dilakukan oleh ibu bekerja yang aktif menyusui untuk memenuhi kebutuhan ASI selama 6 bulan guna menjaga ketahanan keluarga.

Penelitian menggunakan metode kualitatif guna mendapatkan data pokok penelitian dan metode kuantitatif sederhana sebagai data pendukung.

Hasil penelitian menunjukkan bahwa, penggunaan TIK dalam manajemen ASI digunakan sebagai alat bantu untuk memperoleh informasi pendukung yang diperlukan oleh informan dalam menerapkan manajemen ASI. Terdapat gambaran hubungan antara TIK dalam menjaga ketahanan keluarga melalui penerapan manajemen ASI yaitu informasi dan motivasi bagi informan diperoleh melalui penggunaan TIK.
\end{abstract}

Kata kunci : Teknologi Informasi Komunikasi, Manajemen ASI, Ketahanan Keluarga 
Valentina Siwi Saridewi, Armaidy Armawi, dan Djoko Soerjo -- Penggunaan Teknologi Informasi Komunikasi Dalam Manajemen ASI Bagi Ibu Bekerja Guna Menjaga Ketahanan Keluarga (Studi Pada Anggota Grup Facebook Asosiasi Ibu Menyusui Indonesia)

\section{PENGANTAR}

Keluarga sebagai bagian terkecil dari masyarakat memiliki peran dalam meningkatkan derajat kesehatan masyarakat. Masing-masing anggota berperan mewujudkan dan mempertahankan kesehatan dalam keluarga sehingga memberikan kontribusi dalam meningkatkan derajat kesehatan masyarakat. Investasi kesehatan dalam keluarga dapat dimulai sejak dini sebagai modal awal jangka panjang bagi pembangunan yang memiliki orientasi terhadap peningkatan kualitas sumber daya manusia yang harus dilaksanakan secara multi dan lintas sektoral (Syafiq, 2007).

Salah satu peran ibu dalam investasi kesehatan sejak dini yaitu memberikan Air Susu Ibu (ASI) selama 6 bulan sesuai dengan rekomendasi WHO sejak tahun 2001 (Fikawati, 2010). Berbagai penelitian telah menunjukkan keunggulan Air Susu Ibu (ASI). ASI merupakan makanan pertama alami yang dibutuhkan bagi bayi dalam beberapa bulan pertama kehidupannya terutama bagi kebutuhan fisik dan emosional. ASI mudah dicerna oleh sistem tubuh bayi karena mengandung komposisi nutrisi yang seimbang bagi kebutuhannya terutama bagi bayi lahir kurang bulan dimana komposisi tersebut tidak dapat diberikan oleh susu formula (Suradi, 2001). Pemberian ASI pada usia dini merupakan salah satu bentuk investasi dalam mewujudkan sumber daya manusia yang handal. Berdasarkan data yang dikeluarkan oleh Kementerian Kesehatan pada tahun 2013 bahwa pemberian ASI eksklusif di Indonesia sebesar 54.3 persen dengan estimasi absolut bayi tidak ASI eksklusif sebesar 1.903 - 384.270 di Indonesia. Sosialisasi pemberian Air Susu Ibu (ASI) saat ini gencar dilakukan melalui berbagai cara termasuk mengunakan media telekomunikasi. Hal tersebut dilakukan untuk meningkatkan persentase pemberian ASI bagi bayi.

Menurut Novrida (1997), ibu dalam keluarga berperan aktif dalam meningkatkan mutu makanan, pendidikan, kesehatan keluarga melalui tambahan pendapatan sebagai hasil jerih payah bekerja diluar urusan rumah tangga. Masa cuti melahirkan yang berlaku di Indonesia hanya selama 3 bulan sesuai dengan yang tercantum dalam Undang-Undang Republik Indonesia Nomor 13 Tahun 2003 Tentang Ketenagakerjaan. Masa cuti 3 bulan tersebut menyebabkan ibu mulai kembali bekerja pada saat usia anak di bawah 6 bulan. Kondisi demikian mempengaruhi pemberian ASI eksklusif selama 6 bulan. Ibu bekerja yang menyadari keunggulan dan manfaat ASI melakukan berbagai usaha untuk memenuhi kebutuhan ASI selama 6 bulan.

Permasalahan dalam penelitian, yaitu: (1). Bagaimana penggunakan TIK dalam manajemen ASI bagi ibu bekerja ?. (2). Bagaimana implikasi penggunaan TIK dalam manajemen ASI ibu bekerja guna menjaga ketahanan keluarga ?. Tujuan penelitian ini, yaitu : (1). Untuk mengetahui penggunaan TIK dalam manajemen ASI ibu bekerja. (2). Untuk mengetahui implikasi penggunaanTIK dalam manajemen ASI ibu bekerja guna menjaga ketahanan keluarga.

Penelitian dilakukan dengan mengumpulkan data melalui grup Facebook Asosiasi Ibu Menyusui Indonesia (FB AIMI). Informan sebagai sumber data dipilih dengan kriteria, yaitu anggota grup FB AIMI, ibu yang sedang atau pernah menyusui, aktif bekerja pada suatu instansi atau wirausaha. Metode deskriptif kualitatif sebagai metode utama dalam penelitian dengan tujuan untuk 
menggambarkan penggunaan TIK dalam manajemen ASI guna menjaga ketahanan keluarga. Data kualitatif sebagai data pokok diperoleh dari hasil wawancara terhadap 54 informan. Data hasil metode deskriptif kuantitatif sederhana sebagai data pendukung berasal dari informan sebanyak 100 orang dengan menggunakan teknik quota sampling. Teknik quota sampling tersebut digunakan karena populasi dari anggota FB AIMI selalu bertambah setiap hari sehingga tidak dapat ditentukan batasnya secara kuantitatif.

Asosiasi Ibu Menyusui Indonesia (AIMI) merupakan organisasi independen non profit yang dibentuk pada tanggal 21 April 2007 yang dilatarbelakangi oleh kepedulian dari beberapa ibu yang prihatin terhadap kesadaran yang minim terhadap pemberian ASI pada bayi. AIMI memiliki tujuan untuk meningkatkan kesadaran pemberian ASI serta meningkatkan jumlah ibu menyusui. Hal tersebut dilakukan guna mendukung kualitas sumber daya manusia (SDM) di Indonesia. Ketersediaan SDM produktif yang berkualitas dan inovatif dipersiapkan untuk menghadapi tantangan negara di masa mendatang sejak dalam kandungan dan usia dini.

Pengetahuan ibu yang benar tentang ASI menjadi salah satu faktor yang mempengaruhi pemberian ASI (Fahriani, 2014) Bentuk dukungan informasi AIMI melalui penggunaan beberapa media sosial seperti twitter dan facebook agar setiap ibu di Indonesia memiliki pengetahuan terhadap pentingnya pemberian ASI serta memberikan dukungan untuk menyusui. Informasi mengenai pemberian ASI dan hal-hal terkait lainnya dapat diakses melalui Grup Facebook AIMI (FB AIMI) dan website AIMI. Grup FB AIMI sebagai sarana untuk penyebarluasan informasi mengenai hal-hal yang berhubungan dengan ASI baik artikel pengetahuan maupun promosi kegiatan yang dilakukan secara resmi. Grup FB AIMI bersifat tertutup, apabila masyarakat hendak bergabung harus melalui verifikasi akun facebook yang dilakukan oleh administrator. Saat penelitian ini disusun jumlah FB AIMI memiliki lebih dari 139.000 anggota dan akan selalu bertambah setiap harinya.

Administrator grup memberlakukan beberapa peraturan ketat bagi anggota untuk mengantisipasi penyalahgunaan grup dan informasi yang tercantum di dalamnya. Grup tersebut menjadi salah satu cara berinteraksi antara sesama anggota AIMI yang diakses dengan mudah melalui perangkat TIK. Anggota grup dapatbertukar pikiran dalam diskusi, memberikan masukan serta memberikan semangat positif antar sesama anggota. Umumnya tanggapan yang diunggah anggota berupa pengalaman pribadi, empati atau dukungan serta permintaan informasi dalam menanggulangi situasi dan kondisi yang dialami oleh anggota lain terkait topik bahasan yang sedang didiskusikan.

\section{PEMBAHASAN}

Salah satu dampak globalisasi yaitu perkembangan teknologi informasi dan komunikasi. Komunikasi merupakan kebutuhan utama yang memerlukan Teknologi Informasi dan Komunikasi (TIK) sebagai sarana untuk mengatasi permasalahan ruang dan waktu (Wuryanta, 2013). Masyarakat saat ini selalu membutuhkan informasi pada segala aspek kehidupan. Masyarakat memiliki kebebasan dalam mencari, menerima dan memberi informasi serta gagasan melalui media apapun dan tanpa batasan apapun.

Kuhlthau (2015) mengenalkan Proses Pencarian Informasi sebagai model pencarian 
Valentina Siwi Saridewi, Armaidy Armawi, dan Djoko Soerjo -- Penggunaan Teknologi Informasi Komunikasi Dalam Manajemen ASI Bagi Ibu Bekerja Guna Menjaga Ketahanan Keluarga (Studi Pada Anggota Grup Facebook Asosiasi Ibu Menyusui Indonesia)

informasi dengan pendekatan pengalaman holistik. Model tersebut menggambarkan rangkaian dari perasaan, pikiran dan tindakan dalam 6 tahap dimana kejelasan informasi merupakan tujuan yang ingin dicapai. Awalan (initiation) merupakan tahap dimana individu menyadari bahwa ada jarak antara pengetahuan sehingga merasakan ketidakjelasan terhadap sesuatu. Individu berusaha mencari pendekatan untuk mendapatkan pengetahuan terhadap permasalahan. Tahap pemilihan topik yang akan dipelajari (selection) mendorong perasaan optimis dalam memulai pencarian informasi. Tahap penjelajahan (exploration), individu berusaha untuk fokus dan mendapatkan sudut pandang pribadi terhadap informasi dengan cara mencari informasi tentang topik umum dan membaca. Perumusan (formulation) sebagai tahap keempat dalam model ini, pemikiran individu berusaha untuk mengidentifikasi dan memilih ide dari informasi untuk membentuk perspektif yang berfokus pada topik sehingga menjadi lebih personal. Tahap pengumpulan (collection), pemikiran individu semakin terarah sehingga interaksi dengan fungsi sistem menjadi efektif dan efisien. Informasi yang dikumpulkan menjadi lebih terfokus dan rinci terhadap topik Pada tahap akhir yaitu penyajian (presentation), informasi sebagai capaian dipersiapkan untuk disajikan atau digunakan sebagai temuan (tabel 1).

TIK mendukung usaha pemenuhan kebutuhan informasi secara efektif dalam kehidupan sehari-hari terutama sosialisasi kesehatan. Venkatesh (2003) dalam teori terpadu penerimaan dan penggunaan teknologi I unified theory of acceptance and use of technology (UTAUT) menjelaskan beberapa determinan yang dapat menentukan individu dalam menerima dan menggunakan teknologi. Determinan dalam UTAUT yaitu: harapan kinerja, usaha yang diharapkan, pengaruh sosial serta kondisi fasilitas (gambar 1).

Harapan kinerja (performance expectancy) digunakan untuk mengukur kepercayaan individu terhadap manfaat kinerja dari penggunaan TIK. Usaha yang diharapkan (effort expectancy) digunakan untuk mengukur besarnya usaha dalam penggunaan TIK. Pengaruh sosial (social influence) sebagai determinan untuk mengukur pengaruh seorang individu terhadap individu lain agar bergabung menggunakan TIK. Determinan terakhir yaitu kondisi fasilitas (facilitating conditions) untuk mengetahui infrastruktur yang diperlukan dalam penggunaan TIK.

Tabel 1

Model Proses Pencarian Informasi Menurut Kuhlthau

\begin{tabular}{|c|c|c|c|c|c|c|c|}
\hline & Initiation & Selection & Exploration & Formulation & Collection & Presentation & Assessment \\
\hline $\begin{array}{l}\text { Feelings } \\
\text { (Affective) }\end{array}$ & Uncertainty & Optimism & $\begin{array}{l}\text { Confusion } \\
\text { Frustration } \\
\text { Doubt }\end{array}$ & Clarity & $\begin{array}{l}\text { Sense of direction / } \\
\text { Confidence }\end{array}$ & $\begin{array}{l}\text { Satisfaction or } \\
\text { Disappointment }\end{array}$ & \multirow{3}{*}{$\begin{array}{l}\text { Sense of } \\
\text { accomplish- } \\
\text { ment }\end{array}$} \\
\hline Thoughts & vague - & & $\longrightarrow$ & focused & & & \\
\hline $\begin{array}{l}\text { Actions } \\
\text { (Physical) }\end{array}$ & seeking & $\begin{array}{l}\text { relevant } \\
\text { Exploring }\end{array}$ & information & seeking & $\begin{array}{c}\text { pertinent } \\
\text { Documenting }\end{array}$ & information & \\
\hline
\end{tabular}

Sumber : comminfo.rutgers.edu, 2015 
Gambar 1

Model Teori Terpadu Penerimaan dan Penggunaan Teknologi

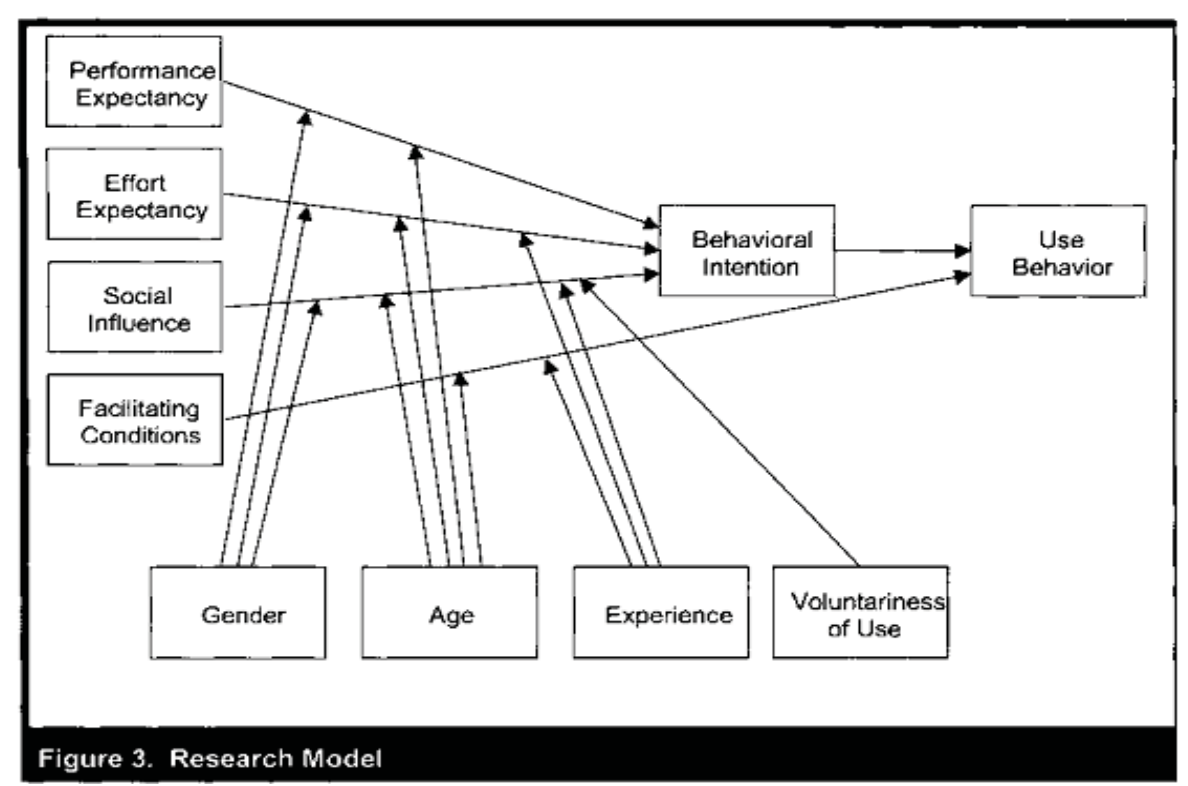

Sumber: Venkatesh, 2003

Beberapa determinan tersebut kemudian akan menentukan niat individu untuk menggunakan TIK. Niat tersebut mendorong individu untuk menerima dan menggunakan TIK. Penggunaan TIK dalam penelitian ini merujuk pada penggunaan komputer atau telepon pintar (smartphone) yang memiliki akses internet oleh individu untuk memenuhi kebutuhan informasi mengenai pemberian ASI.

Keluarga terdiri dari suami-isteri, atau suami-isteri dan anaknya, atau ayah dan anaknya, atau ibu dan anaknya memiliki peran dalam pembentukan sumber daya berkualitas yang mendorong peningkatan kesejahteraan. Dalam meningkatkan kesejahteraan lahir dan kebahagiaan batin, suatu keluarga perlu meningkatkan ketahanan keluarga. Ketahanan keluarga merupakan keuletan dan ketangguhan serta kemampuan fisik-materiil dan psikis-mental spiritual sebuah keluarga pada kondisi dinamik guna hidup mandiri dan mengembangkan keluarga untuk hidup harmonis.
Menurut Sunarti (2003) dalam penelitiannya terdapat 3 faktor yang mendukung ketahanan keluarga, yaitu: (1). Ketahanan fisik memberikan gambaran bahwa semakin baik sumber daya fisik maka semakin rendah masalah fisik. Penanggulangan masalah semakin baik dalam sebuah keluarga mendorong kesejahteraan fisik semakin baik. (2). Ketahanan sosial digambarkan pada sumberdaya non fisik semakin baik maka penanggulangan masalah non fisik menjadi rendah. (3). Ketahanan psikologis menggambarkan bahwa rendahnya masalah keluarga non fisik yang dialami maka kesejahteraan psikologis menjadi semakin baik (gambar 2).

Kesejahteraan keluarga dapat ditingkat melalui peningkatan pendapatan keluarga. Pendapatan ibu bekerja memberikan kontribusi dalam meningkatkan pendapatan keluarga. Oleh karena itu, guna meningkatkan pendapatan keluarga maka ibu yang telah 
Gambar 2

Model Teori Terpadu Penerimaan dan Penggunaan Teknologi

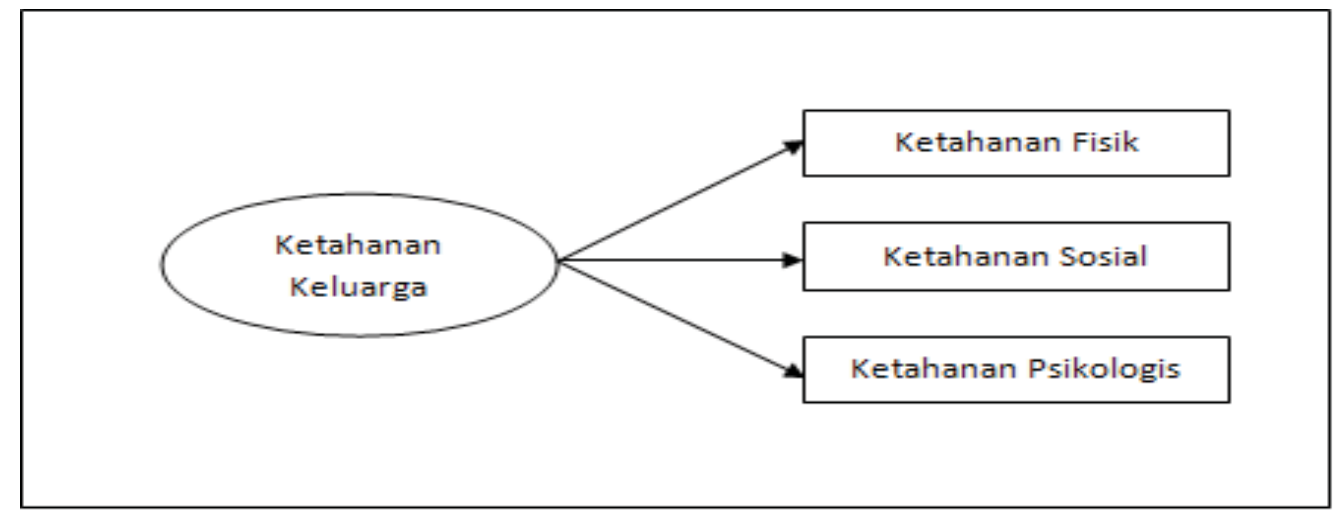

Sumber: Sunarti, 2003

melaksanakan cuti melahirkan segera kembali bekerja. Kendala yang dihadapi saat ibu menyusui mulai bekerja dan niat untuk terus memberikan ASI. Salah satu solusi agar ibu bekerja tetap dapat memberikan ASI dengan menerapkan manajemen ASI. Melalui manajemen ASI, ibu bekerja perlu mengelola berbagai sumber daya secara efektif dengan tujuan untuk memberikan ASI minimal 6 bulan.

Proses awal mencari informasi dimulai oleh kesadaran terdapat celah terhadap informasi yang belum diketahui (Kuhlthau, 2015). Kesadaran yang dialami para informan yaitu terdapat celah antara keinginan memberikan ASI minimal 6 bulan dengan kondisi untuk kembali bekerja. Ketidaktahuan ibu bekerja menyusui terhadap cara agar bayi memperoleh ASI mendorong informan untuk menggunakan perangkat TIK. Penggunaan TIK sebagai usaha untuk memperoleh informasi agar tetap dapat memberikan ASI selama ibu bekerja.

Ibu menyusui mendapatkan informasi mengenai laktasi melalui buku-buku tentang ASI/menyusui, konsultasi atau mengikuti pelatihan laktasi dengan narasumber laktasi secara langsung. Pihak medis berwenang yang mendukung dalam pemberian ASI atau konselor laktasi/menyusui dalam penelitian ini selanjutnya disebut sebagai narasumber laktasi. Beberapa kendala yang dihadapi melalui cara tersebut, yaitu: keterbatasan waktu, biaya, keterbatasan narasumber laktasi di daerah terpencil. Kendala yang dihadapi sebagai ibu bekerja dengan banyak kesibukan tetapi memiliki niat dan usaha untuk tetap memberikan ASI mendorong rasa optimis para informan untuk mencari informasi.

Para informan mendapatkan solusi dengan memanfaatkan kemudahan penggunaan TIK. Para informan menggunakan browser yang terpasang dalam perangkat TIK seperti Internet Explorer, Chrome, Mozilla dan lain sebagainya. Melalui browser para informan dapat mengakses situs-situs yang menyediakan layanan mesin pencarian informasi seperti Google, Bing, Yahoo, dan sebagainya. Mesin pencari tersebut kemudian menampilkan tautan seluruh situs yang mengandung kata kunci yang telah dimasukkan.

Jumlah tautan muncul dengan cepat dalam jumlah yang sangat banyak. Alternatif lain untuk mendapatkan informasi dengan 
bergabung dalam komunitas melalui media internet. Komunitas dalam penelitian ini yaitu FB AIMI. Melalui FB AIMI para informan dapat melakukan diskusi serta meningkatkan motivasi. Diskusi dilakukan dengan narasumber laktasi atau sesama anggota. Grup FB AIMI menyediakan banyak artikel yang dibuat oleh konselor laktasi sehingga dapat dipertanggungjawabkan isi informasi tersebut. Para anggota diperkenankan untuk memberikan tanggapan terkait artikel. Hal tersebut menjadikan informasi menjadi lebih lengkap dan beragam mengenai manajemen ASI sehingga dapat menjadi bahan pertimbangan bagi para informan. Penggunaan TIK berdasarkan model proses pencarian informasi pada tahap inisiasi dan seleksi topik yang dialami oleh para informan sangat membantu dalam mempersingkat waktu. Informan dapat memilih informasi yang dibutuhkan lebih detail dan fokus dari tautan yang dihasilkan oleh mesin pencari informasi.

Rentang usia informan dalam penelitian ini 56 persen berusia 26-30 tahun dan 23 persen berusia 31-35 tahun. Rentang usia 26-30 tahun termasuk dalam generasi Y yang terbiasa dalam penggunan TIK. Akses internet saat ini menjadi gaya hidup untuk memenuhi kebutuhan informasi. Hampir seluruh informan tidak mengalami kendala dalam pengoperasian TIK. Kendala yang dihadapi para informan lebih umum terkait pada fasilitas pendukung perangkat TIK seperti ketersediaan layanan jaringan komunikasi internet dan ketersediaan listrik.

Lingkungan sosial memberikan pengaruh terutama saat pertama kali terhadap individu menggunakan TIK (Venkatesh, 2003). Berdasarkan data pendukung diperoleh gambaran 66 persen informan menyatakan setuju bahwa lingkungan sosial mempengaruhi informan untuk menggunakan TIK, dan 76 persen menunjukkan lingkungan sosial mendukung informan dalam penggunaan TIK. Pengaruh sosial menjadi salah satu komponen yang memiliki peranan kuat terhadap niat penggunaan TIK yang memberi pengaruh terhadap output (Oswari, 2008). Beberapa hal yang mempengaruhi informan untuk menggunakan TIK, yaitu: inisiatif sendiri yang dipengaruhi oleh kondisi lingkungan sosial, keluarga, rekan kerja/teman, serta komunitas. TIK. Penggunaan TIK sebagai sarana untuk menanggulangi masalah keluarga dalam proses pemenuhan kebutuhan informasi mengenai manajemen ASI. Salah satu hasil penggunaan TIK, informan dianggap memiliki pengetahuan manajemen ASI yang cukup oleh lingkungan sosial. Pengetahuan tersebut mendorong lingkungan sosial tertarik untuk mengetahui hal-hal mengenai manajemen ASI serta mengundang permintaan terhadap informasi yang diketahui informan.

Kondisi fasilitas dalam model UTAUT merupakan determinan dimana individu memerlukan infrastruktur TIK dan fasilitas pendukung lainnya. TIK sebagai aset keluarga menjadi salah satu sumber daya dalam komponen input ketahanan keluarga. Akses informasi pada dunia maya memerlukan perangkat TIK yang terhubung dengan internet sehingga informan memerlukan sarana dan prasarana dalam bidang TIK. Beberapa hal yang diperlukan oleh para informan untuk menggunakan TIK, yaitu: (1). Perangkat keras yang berupa komputer atau smartphone yang mendukung akses internet. (2). Ketersediaan layanan jaringan telekomunikasi yang diperlukan 
Valentina Siwi Saridewi, Armaidy Armawi, dan Djoko Soerjo -- Penggunaan Teknologi Informasi Komunikasi Dalam Manajemen ASI Bagi Ibu Bekerja Guna Menjaga Ketahanan Keluarga (Studi Pada Anggota Grup Facebook Asosiasi Ibu Menyusui Indonesia)

untuk mengakses internet. (3). Biaya untuk membeli layanan jaringan telekomunikasi. Informan perlu mengalokasikan dana untuk mendapatkan akses internet melalui provider jaringan telekomunikasi. (4). Listrik untuk mengoperasikan perangkat TIK (gambar 3).

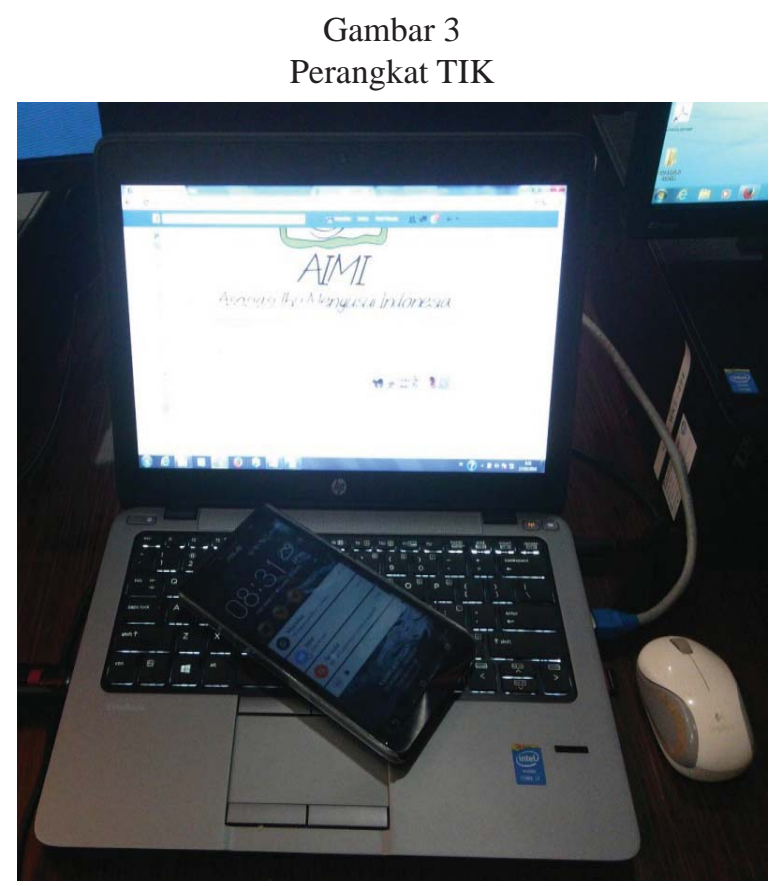

Sumber: data pokok

Penggunaan TIK dengan tujuan memperoleh informasi mengenai manajemen ASI memerlukan beberapa kemampuan, yaitu pengoperasian komputer dan kemampuan memilah informasi yang tepat. Informan perlu memiliki kemampuan mengoperasikan perangkat TIK agar dapat mengakses informasi dengan mudah. Teknologi komunikasi memungkinkan komunikasi tanpa batas ruang dan waktu sehingga membantu kebutuhan individu dalam menyediakan informasi melalui komunikasi yang cepat, murah dan tepat (Triratnawati, 2003). Berdasarkan data pokok didapatkan bahwa para informan membutuhkan informasi manajemen ASI dengan cepat dan mudah didapat. Kemudahan menjadi alasan para informan menggunakan TIK. Beberapa kelebihan penggunaan TIK yang dirasakan informan, yaitu: kemudahan penggunaan, efektif dan efisien terhadap waktu, serta hemat. TIK memberikan kemudahan terutama bagi informan didaerah yang belum didukung oleh ketersediaan narasumber laktasi.

Pengetahuan akan mempengaruhi individu dalam berperilaku yang mendorong seseorang untuk berbuat (Yani, 2009). Pengetahuan informan merupakan bagian dari sumberdaya non fisik sebagai komponen input dalam ketahanan keluarga guna penerapan manajemen ASI. Berdasarkan informasi pentingnya ASI yang diperoleh melalui penggunaan TIK mendorong informan untuk menerapkan manajemen ASI dengan harapan memenuhi kebutuhan yang terbaik bagi bayi.

Latar belakang informan menerapkan manajemen ASI, yaitu: (1). Kepedulian terhadap anggota keluarga. Para informan sebagai ibu dalam keluarga berusaha untuk memenuhi kebutuhan dasar anak yaitu salah satunya kebutuhan hidup (Juzak, 1997). Kebutuhan hidup bayi berupa kebutuhan akan ASI. (2). Status ibu bekerja. Kondisi keluarga menuntut ibu untuk ikut bekerja karena kesadaran bahwa wanita memiliki peran ganda untuk bekerja mencari nafkah guna menutupi kekurangan ekonomi keluarga serta bekerja di rumah (Novrida, 1997). Ibu bekerja mencari informasi mengenai cara agar dapat memenuhi kebutuhan ASI saat tidak bersama bayi. (3). Menekan biaya pengeluaran. Pemenuhan kebutuhan nutrisi bagi bayi dengan ASI dirasakan jauh lebih hemat dibandingkan susu formula. Harga susu formula yang tinggi 
mendorong informan berusaha memberikan ASI dalam kondisi ibu tetap bekerja. Keempat, pengalaman pemberian ASI pada anak sebelumnya.

Penerapan manajemenASI menggunakan sarana dan sumber daya manusia. Sarana terdiri dari hal-hal yang berhubungan dengan penyediaan ASI secara benar. Penerapan manajemen ASI tidak bisa dilakukan oleh ibu bekerja sendiri tetapi memerlukan dukungan dengan orang-orang di sekitar. Sumber daya manusia (SDM) diperlukan dalam penerapan manajemen ASI. SDM yang dimaksud meliputi informan, pengasuh, dan narasumber laktasi. Pengasuh dalam hal ini adalah orang yang bertanggung jawab untuk memberikan ASI menggunakan media yang benar. Informan perlu membekali diri dengan informasi tentang ASI yang benar sebelum menerapkan manajemen ASI.

Informasi yang benar mengenai pengelolaan ASI menjadi modal awal dalam penerapan majemen ASI. informasi tersebut menjadi bahan sosialisasi bagi orang-orang di sekitar informan baik dalam keluarga maupun di tempat kerja. Hambatan yang sering dialami oleh informan yaitu masyarakat belum memahami pentingnya ASI serta kebiasaan atau budaya yang berlaku di masyarakat. Banyak mitos-mitos yang masih dipercaya oleh lingkungan sekitar informan sehingga sulit menerima informasi baru yang tidak sesuai dengan kebiasaan.

Umumnya yang terjadi di masyarakat, bayi diberikan susu formula saat ibu mulai bekerja kembali. Hal demikian terjadi karena anggapan bahwa ibu bekerja tidak bisa memberikan ASI dan manajemen ASI belum banyak diketahui oleh masyarakat. Beberapa informan mengutarakan bahwa masih ada masyarakat yang berasumsi apabila bayi rewel karena ASI yang kurang sehingga mendorong keputusan untuk memberikan susu formula dengan keyakinan bahwa kandungan gizi yang lebih baik. Penilaian yang salah terhadap penampilan fisik ASI sehingga menimbulkan kesan bahwa nutrisi yang terkandung tidak selengkap susu formula. Anggapan salah di masyarakat jika bayi hanya mengkonsumsi ASI selama 6 bulan tidak memiliki tubuh yang gemuk sehingga dinilai kurang sehat. Alasan lain memberikan susu formula karena lebih praktis. Oleh karena itu, dalam mengahadapi hambatan tersebut, informan perlu memiliki kesabaran memberikan informasi ASI yang benar pada lingkungan sekitar.

Upaya yang dilakukan informan untuk mendapatkan informasi, antara lain: mengakses sumber informasi dan melakukan diskusi. Informan dapat mengakses sumber informasi yang membahas informasi terkait secara lebih detail melalui internet atau bukubuku referensi. Informan menggunakan TIK secara optimal guna mendapatkan informasi ASI pada dunia maya. Sumber informasi manajemen ASI didapatkan melalui situs dan media sosial. TIK dalam menmyebarluaskan informasi memberikan konsekuensi bagi individu untuk menghadapi ledakan informasi. Ledakan informasi terjadi sebagai akibat pertumbuhan yang sangat cepat terhadap informasi yang dipublikasikan. Ledakan informasi pada satu sisi memberikan banyak informasi yang dibutuhkan tetapi di sisi lain menimbulkan kesulitan bagi individu dalam mencerna informasi yang diterima karena peluang muncul informasi yang saling bertolak belakang (Wuryanta, 2013). Ledakan informasi sebagai konsekuensi hasil pencarian informasi menuntut informan untuk dapat 
Valentina Siwi Saridewi, Armaidy Armawi, dan Djoko Soerjo -- Penggunaan Teknologi Informasi Komunikasi Dalam Manajemen ASI Bagi Ibu Bekerja Guna Menjaga Ketahanan Keluarga (Studi Pada Anggota Grup Facebook Asosiasi Ibu Menyusui Indonesia)

memilih informasi yang akurat sehingga dapat dijadikan informasi pendukung pengetahuan dasar mengenai manajemen ASI. Hal tersebut dilakukan karena tidak menutup kemungkinan menghasilkan informasi yang bias sehingga perlu dilakukan proses verifikasi dan validasi terhadap informasi yang telah diperoleh.

Beberapa cara yang dilakukan para informan dalam memilih informasi, yaitu : (1). Membandingkan suatu artikel dengan beberapa artikel lain kemudian mengambil kesimpulan dari hal umum yang tercantum dalam artikel tersebut. (2). Memanfaatkan tanggapan atau diskusi para pembaca tentang topik terkait apabila umumnya pembaca memberikan tanggapan setuju terhadap artikel tersebut maka informan menggunakan sebagai salah satu masukan. (3). Mendapatkan informasi yang berasal dari penelitian yang telah dilakukan oleh institusi resmi. (4). Informan mengumpulkan informasi terkait manajemen ASI kemudian mendiskusikan dengan narasumber laktasi. Apabila informan tidak berhasil memperoleh informasi yang akurat maka perlu melakukan konsultasi dengan narasumber laktasi guna verifikasi informasi (Wibowo, 2014). Diskusi dengan narasumber laktasi dapat dilakukan melalui pelatihan terkait manajemen ASI atau konsultasi. Konsultasi dilakukan dengan bertatap muka secara langsung maupun dengan media telekomunikasi.

Komputer sebagai salah satu fasilitas teknologi informasi akan memiliki fungsi sosial jika terhubung dengan internet (Bell, 2006). Cara lain memperoleh informasi melalui media sosial. Media jejaring sosial melalui internet sangat efektif sebagai media difusi informasi tanpa kendala ruang (Laksono, 2011). Facebook sebagai salah satu media jejaring sosial yang memanfaatkan TIK memiliki peranan dalam penyebarluasan informasi antar sesama pemilik akun facebook. Ibu menyusui mendapatkan informasi tentang pemberian ASI eksklusif melalui media sosial (Melasari, 2014). Banyak komunitas-komunitas yang dibentuk melalui media sosial. Komunitas tersebut dibentuk untuk mengumpulkan individu-individu yang memiliki kepentingan dan kebutuhan yang sama. Informan dapat bergabung dalam komunitas yang mendukung pemberian ASI dalam hal ini FB AIMI. Tujuan informan bergabung dalam FB AIMI guna mendapatkan informasi mengenai ASI. FB AIMI memberikan kesempatan informan dapat berkonsultasi dengan mengirimkan pesan dan berdiskusi dengan narasumber. Melalui komunitas pada FB AIMI para informan dapat melakukan diskusi dengan narasumber laktasi dan sesama anggota serta membantu meningkatkan motivasi untuk menerapkan manajemen ASI. Berbagi pengalaman dalam komunitas sangat berperan dalam menghadapi motivasi menurun yang dialami oleh para informan. Perasaan bahwa masalah dialami dirasakan oleh ibu-ibu lain dapat meningkatkan motivasi yang berkurang. Tanggapan anggota berupa masukkan sehingga tercipta diskusi terhadap permasalahan yang dihadapi berkontribusi untuk meningkatkan motivasi informan yang menurun.

Para informan bergabung dalam sebuah komunitas agar tetap fokus terhadap informasi yang dibutuhkan. Diskusi dilakukan oleh informan baik dengan ibu menyusui lain maupun dengan narasumber laktasi. Diskusi dengan anggota FB AIMI secara langsung atau dengan ibu menyusui yang ada di sekitar informan yang pernah menerapkan manajemen ASI. Diskusi tersebut menghasilkan masukkan 
dari pengalaman menerapkan manajemen ASI. Kendala dalam diskusi menggunakan media sosial yaitu tanggapan yang disampaikan menggunakan bahasa pergaulan atau singkatan yang tidak diketahui oleh seluruh anggota. Kendala tersebut menyebabkan informan gagal dalam memahami isi pesan yang disampaikan. Pendapat antar anggota yang bersinggungan membuat saling serang. Administrator FB AIMI menerapkan berbagai aturan secara tegas dan keras untuk ketertiban dan kenyamanan semua pihak.

Informan mengumpulkan informasi valid dan sesuai dengan kondisi yang dialami. Tahap akhir dalam model proses pencarian informasi yaitu penyajian informasi yang telah dikumpulkan oleh informan. Apabila informan telah berhasil mengumpulkan informasi yang diinginkan dan merasa puas maka penyajian informasi diwujudkan dengan berbagi informasi dengan orang-orang di lingkungan sekitar dan menerapkannya. Hasil penggunaan TIK sangat dirasakan bagi informan terutama bagi yang berada di daerah yang tidak tersedia narasumber laktasi.

Pengetahuan masyarakat tentang pentingnya ASI mempengaruhi motivasi dan dukungan dalam penerapan manajemen ASI. Pada awal penerapan ASI muncul kekhawatiran jika produksi ASI tidak dapat memenuhi kebutuhan bayi selama 6 bulan. Kurangnya motivasi dan dukungan dapat menjadi hambatan dalam penerapan manajemen ASI. Motivasi memberikan ASI mendorong ibu menyusui terus berusaha memproduksi ASI dalam berbagai kondisi yang dialami. Semangat menjadi hal saat motivasi menurun. Usaha yang dilakukan para informan agar tetap memiliki motivasi yaitu meluangkan waktu untuk istirahat dan berusaha berpikir positif bahwa ASI merupakan yang terbaik bagi anak. Komunitas berperan dalam meningkatkan motivasi bagi anggota. Motivasi meningkatkan kepercayaan diri untuk memenuhi kebutuhan ASI bagi bayi selama minimal 6 bulan. Diharapkan motivasi kuat mendukung niat dan kepercayaan diri untuk berupaya menyediakan ASI perah ditengahtengah kurangnya dukungan dan anggapan kurang positif di dalam masyarakat.

Perbedaan pengetahuan ASI antara informan dengan lingkungan sosial kerapkali menimbulkan perselisihan karena belum dapat menerima pengetahuan baru mengenai ASI. Acuan pada pengalaman dan pola lama masih berlaku di masyarakat. Anggapan masyarakat bahwa perbedaan yang terlihat antara bayi mengkonsumsi susu formula dengan bayi yang hanya mengkonsumsi ASI adalah berat badan. Anggapan tersebut menimbulkan kekhawatiran anggota keluarga atau lingkungan terdekat informan. Anggota keluarga yang khawatir kemudian menyarankan untuk memberikan susu formula bagi bayi kurang dari 6 bulan dengan agar berat badan bertambah.

Hambatan dalam penerimaan dukungan informasi dari orang tua dan mertua dalam rangka pemeliharaan keberhasilan pemberian ASI eksklusif setelah persalinan akibat keterbatasan informasi (Wibowo, 2014). Informan perlu berupaya untuk memastikan bahwa lingkungan sekitar mendapatkan informasi yang benar mengenai ASI dalam usaha untuk menerapkan manajemen ASI. Tidak mudah bagi informan untuk memberikan penjelasan mengenai manajemen ASI sebagai hal baru dan tidak sesuai kebiasaan yang berlaku di masyarakat. Diperlukan kesabaran dalam melakukan sosialisasi informasi tentang manajemen ASI yang benar dalam 
Valentina Siwi Saridewi, Armaidy Armawi, dan Djoko Soerjo -- Penggunaan Teknologi Informasi Komunikasi Dalam Manajemen ASI Bagi Ibu Bekerja Guna Menjaga Ketahanan Keluarga (Studi Pada Anggota Grup Facebook Asosiasi Ibu Menyusui Indonesia)

keluarga dan lingkungan sosial. Sosialisasi manajemen ASI membutuhkan komunikasi yang baik. Tidak jarang komunikasi yang kurang baik di antara keluarga menimbulkan masalah dalam penerapan manajemen ASI. Dukungan keluarga merupakan salah satu faktor yang dapat memberikan peluang 3,24 kali bagi ibu untuk memberikan ASI eksklusif pada bayi (Hastuti, 2014). Berdasarkan data pendukung, sebagian besar para informan dalam menerapkan manajemen ASI didukung oleh keluarga inti terutama suami.

Sosialisasi, koordinasi dan dukungan dengan pengasuh dalam memberikan ASI perah menggunakan media yang benar. Informan perlu membiasakan bayi mengkonsumsi ASI perah sebelum mulai bekerja kembali. Hal tersebut dilakukan untuk mengubah pola lama pengasuhan bayi yang berlaku di lingkungan informan. Informan perlu berkomunikasi dengan baik dan terus menerus mengingatkan pengasuh untuk menyiapkan dan memberi ASI perah dengan benar. Pemberian ASI perah perlu melakukan beberapa langkah yang perlu dilakukan sehingga waktu yang dibutuhkan tidak singkat. Setelah lingkungan sosial menerima manajemen ASI selanjutnya membutuhkan waktu untuk terus berlatih dalam beradaptasi dengan kebiasaan baru. Perlu latihan secara kontinu untuk membiasakan diri dalam proses penerapan manajemen ASI.

Jumlah persediaan ASI perah yang dibutuhkan bayi bertambah seiring dengan pertumbuhannya menjadi perhatian utama bagi ibu bekerja. Setiap hari informan perlu menyiapkan persediaan ASI perah yang dikonsumsi pada hari berikutnya. Kondisi tersebut menuntut informan untuk menyediakan ASI perah beberapa botol dalam sehari. Beberapa kendala yang dialami informan terkait dalam penurunan jumlah persediaan ASI perah, yaitu (1). Produksi ASI menurun disebabkan oleh kondisi yang dialami oleh ibu bekerja. Penyebab produksi ASI menurun umumnya karena tidak memerah ASI secara konsisten. (2). Perjalanan dinas ke luar kota mengurangi kesempatan menyusui bayi serta kesempatan memerah ASI. (3). Kondisi fisik dalam keadaan tidak sehat.

Beberapa upaya yang dilakukan informan untuk mengatasi kendala saat jumlah persediaan ASI menurun, yaitu: (1). Dengan menjaga kesehatan dan pikiran. Upaya tersebut dilakukan dengan mengkonsumsi makanan bergizi istirahat dan cukup serta menjaga pikiran agar selalu positif karena berpengaruh dalam produksi ASI. (2). Menerapkan disiplin memerah. Informan perlu mengelola waktu dengan baik antara waktu yang dibutuhkan untuk menyelesaikan pekerjaan dengan penggunaan waktu yang terbatas secara maksimal untuk dapat memerah ASI secara konsisten (gambar 4).

Hambatan yang dialami para informan di lingkungan kerja berhubungan dengan kondisi pekerjaan, waktu, sarana, hingga sikap negatif rekan kerja. Perjalanan dinas dengan frekuensi tinggi, kesibukan bekerja dan beban kerja yang banyak menyebabkan waktu terbatas untuk memerah ASI. Kesibukan dalam bekerja membuat beberapa informan melewatkan waktu di sela-sela pekerjaan untuk memerah ASI. Ketersediaan ruang laktasi seringkali membuat aktivitas memerah ASI menjadi tidak optimal. Tidak jarang pula fasilitas ruang laktasi yang tersedia disalahgunakan oleh rekan kerja kerap kali dirasakan informan. Hambatan yang dihadapi kerapkali membuat para informan tidak melakukan aktivitas memerah ASI. Pandangan negatif rekan kerja 
Gambar 4

Output Kegiatan Laktasi Di Kantor

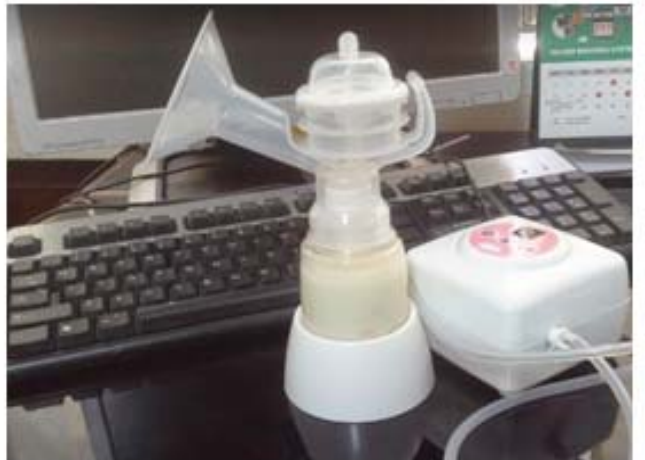

Sumber: data pokok

lawan jenis dengan menjadikan lelucon tidak pantas sehingga membuat informan merasa tidak nyaman untuk memerah ASI. Sikap negatif dengan meremehkan dilakukan oleh rekan kerja yang memberikan susu formula bagi bayi dan kadang memberikan pendapat yang menyinggung perasan terkait dengan penerapan manajemen ASI.

Menanggulangi hambatan tersebut dibutuhkan pemahaman informasi mengenai ASI yang benar di lingkungan kerja. Penerapan manajemen ASI di lingkungan kerja membutuhkan dukungan dari pimpinan dan rekan kerja. Dukungan diberikan oleh pimpinan dan rekan kerja apabila telah memahami pentingnya ASI. Dukungan dari pimpinan berupa toleransi waktu untuk melakukan aktivitas memerah ASI serta penyediaan fasilitas laktasi. Dukungan rekan kerja yang dirasakan oleh informan berupa semangat, memberikan masukan, mengingatkan jadwal memerah, usulan pengadaan atau menyediakan ruang laktasi sampai dengan kesediaan rekan kerja membantu menyelesaikan pekerjaan. Pengalaman informan terhadap kendala minim fasilitas ruang laktasi yaitu kesediaan rekan kerja membantu meminjamkan ruangan agar dapat memerah ASI.
Hal lain dalam menerapkan manajemen ASI pada lingkungan kerja yaitu manajemen waktu dan penerapan disiplin untuk memerah, pemahaman prinsip first in first out, serta pemahaman prinsip supply and demand. Informan perlu mengelola waktu dengan baik agar dapat memerah ASI. Informan meluangkan waktu di sela-sela pekerjaan kantor disesuaikan kondisi pekerjaan apabila memerah ASI dilakukan dengan tidak rileks akan memberikan hasil yang tidak optimal. Pemanfaatan waktu istirahat menjadi solusi para informan. Pengelolaan waktu yang tepat maka pekerjaan dapat terselesaikan dengan baik. Prinsip supply and demand berhubungan dengan keadaan diri informan. ASI yang diproduksi oleh tubuh dipengaruhi oleh frekuensi dan jumlah ASI yang dikeluarkan.

Prinsip first in first out diterapkan pada saat penyajian ASI perah kepada bayi. Bayi tetap mendapatkan ASI meski sang ibu harus bekerja karena manajemen ASI menjamin ketersediaan ASI perah. Pengaturan pemberian ASI perah perlu dilakukan dengan baik agar tidak terjadi kelebihan persediaan. ASI perah memiliki daya tahan yang terbatas oleh waktu dan kondisi tempat penyimpanan. Informan dapat mendonorkan 
Gambar 5

ASI Perah Tersimpan Dalam Lemari Pendingin

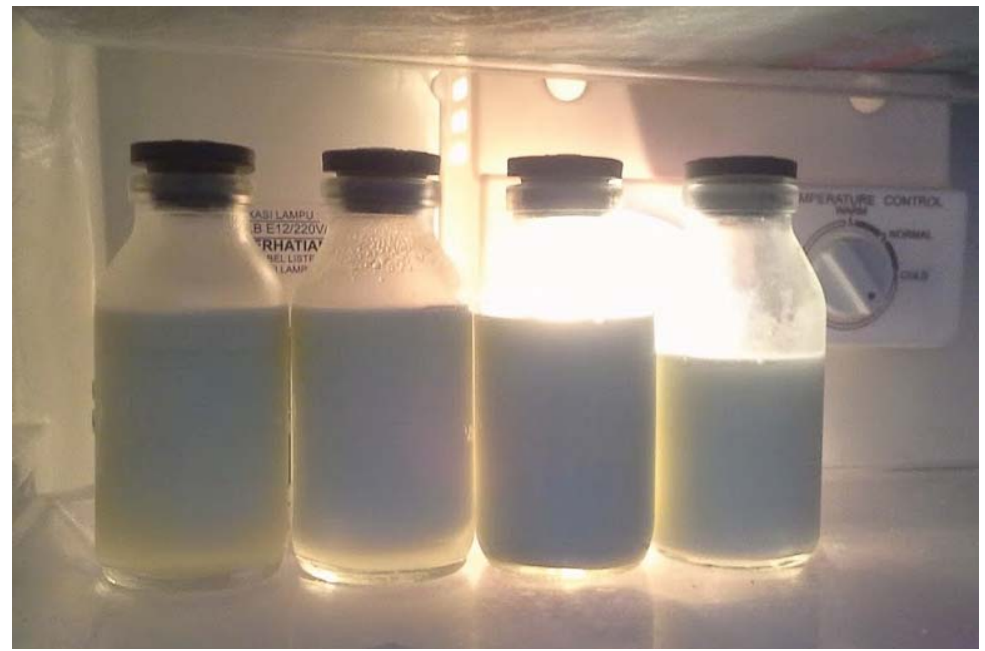

Sumber: data pokok

ASI dengan memperhatikan hal-hal yang tidak menyimpang dari prosedur donor ASI apabila terjadi kelebihan persediaan ASI (gambar 5).

Observasi dan evaluasi penerapan manajemen ASI dilakukan secara berkala. Observasi dan evaluasi dalam penerapan manajemen ASI berfungsi untuk menilai pengetahuan yang dimiliki oleh informan telah dilaksanakan dengan benar, tepat sasaran dan mengetahui hambatan yang dihadapi. Solusi diperoleh bila informan mengetahui hambatan yang dihadapi. Hasil observasi dan evaluasi dapat digunakan untuk memberikan saran dan informasi yang diperlukan untuk penerapan manajemen ASI selanjutnya.

Dampak negatif penerapan manajemen ASI yaitu pertengkaran dan kerepotan yang dirasakan, 3 dari 54 informan menjelaskan bahwa pengetahuan ASI kerap menimbulkan perbedaan pendapat di antara anggota keluarga besar. Penyebab perbedaan pendapat karena kekhawatiran bayi kekurangan asupan dan budaya pengasuhan bayi yang berlaku lingkungan keluarga besar, 8 dari 54 informan menyatakan dampak negatif yaitu kerepotan dalam penerapan. Kerepotan menerapkan manajemen ASI karena menggunakan banyak peralatan dalam menyediakan ASI perah dan membutuhkan kesabaran dalam memberikan ASI perah kepada bayi menggunakan media yang benar.

Informan memerlukan niat dan komitmen kuat dalam menerapkan manajemen ASI karena berbagai tantangan yang dihadapi. Perasaan puas dan bangga dirasakan oleh informan ketika mendapatkan informasi yang benar kemudian berhasil diterapkan. Beberapa perasaan positif yang dialami informan pada saat menerapkan manajemen ASI, yaitu senang, puas, bahagia, bangga, optimis, lega dan bersemangat. Informan merasa bangga apabila berhasil memenuhi kebutuhan ASI minimal 6 bulan. Bangga karena dapat memenuhi kebutuhan ASI meskipun harus melalui berbagai kerepotan untuk menyiapkannya hingga menjadi kebiasaan. Rasa bangga tidak hanya dirasakan oleh ibu bekerja tetapi juga oleh keluarga terhadap keberhasilan penerapan 
manajemen ASI. Penerapan manajemen ASI membuat informan merasa aman bahwa bayi yang ditinggalkan bekerja tetap mendapatkan ASI untuk memenuhi kebutuhannya. Perasaan positif informan merupakan hasil setelah merasakan manfaat penerapan manajemen ASI kemudian mendorong keinginan mensosialisasikan informasi manajemen ASI bagi orang di sekitar.

Dampak positif penerapan manajemen ASI, yaitu: (1). Kebutuhan ASI sebagai hak bayi selama minimal 6 bulan terpenuhi dengan baik. (2). Penghematan pengeluaran keluarga. Penerapan manajemen ASI berkontribusi dalam penghematan pengeluaran keluarga karena tidak menggunakan susu formula selama 6 bulan pertama. (3). Keluarga dapat membedakan antara mitos dan fakta yang berkembang di masyarakat mengenai ASI. Keluarga memiliki keyakinan terhadap penerapan manajemen ASI yang dilakukan sehingga menjadi lebih peduli dan memberikan dukungan yang besar bagi ibu bekerja.

Kaitannya penggunaan TIK dalam menjaga ketahanan keluarga yaitu menjadi bagian dalam komponen input, komponen proses, dan komponen output. Perangkat TIK sebagai aset keluarga menjadi sumberdaya fisik dalam penerapan manajemen ASI. Keluarga memiliki minimal satu perangkat TIK diakui oleh 90 persen informan sebagai anggota FB AIMI. Perangkat TIK berfungsi sebagai alat memperoleh informasi pendukung mengenai manajemen ASI agar dapat diterapkan (gambar $6)$.

Waktu yang terbatas menjadi sumber daya non fisik yang mendorong informan untuk menggunakan TIK. Penggunaan TIK menghasilkan pengetahuan menjadi dasar penerapan manajemen ASI. Informasi yang digunakan untuk mengedukasi lingkungan sosial baik anggota keluarga inti maupun besar, serta rekan kerja. Tujuan sosialisasi agar informan mendapatkan dukungan dalam menerapkan manajemen ASI. Sebagian besar informan memiliki tujuan dalam menerapkan manajemen ASI. Tujuan jangka panjang yaitu menghasilkan kualitas sumber daya manusia yang baik bagi generasi penerus keluarga. Sedangkan tujuan jangka pendek yang ingin

Gambar 6

Kerangka Penggunaan Teknologi Informasi Komunikasi Kaitannya Manajemen ASI Bagi Ibu Bekerja Guna Menjaga Ketahanan Keluarga

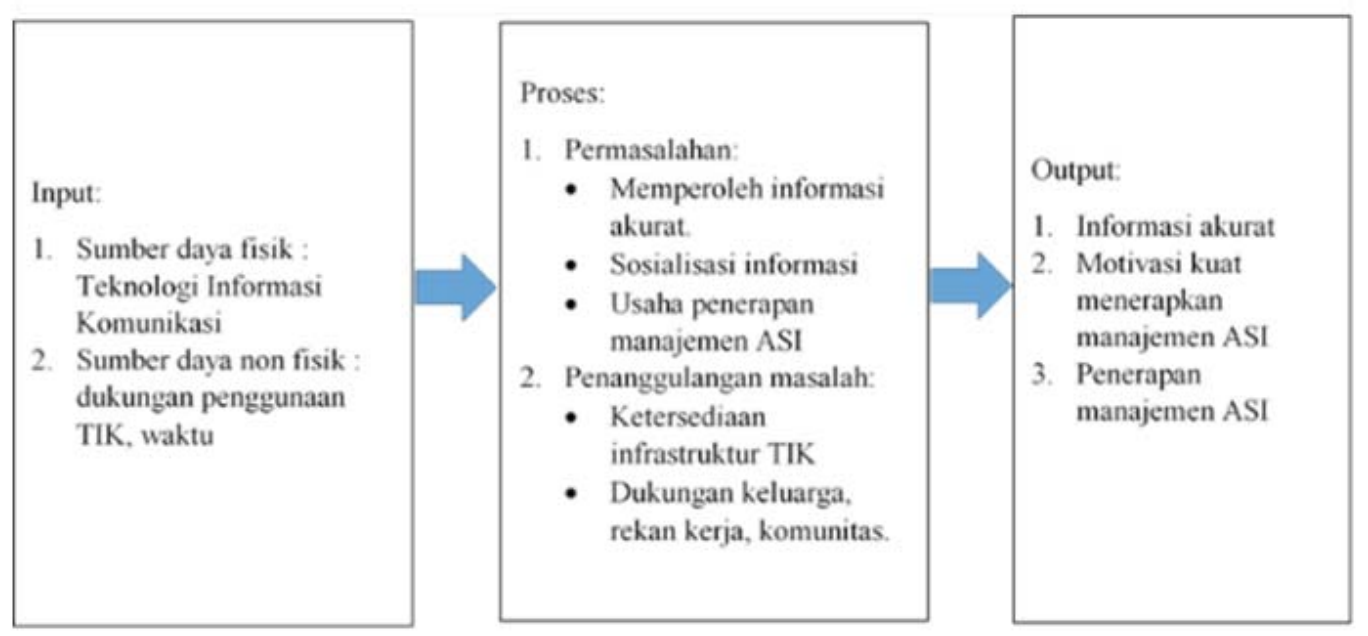

Sumber: olahan peneliti 
Valentina Siwi Saridewi, Armaidy Armawi, dan Djoko Soerjo -- Penggunaan Teknologi Informasi Komunikasi Dalam Manajemen ASI Bagi Ibu Bekerja Guna Menjaga Ketahanan Keluarga (Studi Pada Anggota Grup Facebook Asosiasi Ibu Menyusui Indonesia)

dicapai yaitu pemenuhan hak ibu dan anak. Pemenuhan hak ibu dan anak berupa pemenuhan kebutuhan makanan terbaik bagi pada usia bayi dan perwujudan kasih sayang.

Pada proses penerapan manajemen ASI, TIK berperan dalam penanggulangan masalah. Pelaksanaan manajemen ASI bukan berarti tanpa hambatan. Informan menggunakan TIK untuk mencari solusi terhadap masalah yang dihadapi dalam penerapan manajemen ASI. Terkait dengan permasalahan tersebut, informan perlu mendapatkan informasi akurat mengenai ASI. Berbagai cara dapat dilakukan untuk memperoleh informasi tersebut seperti melakukan pencarian langsung atau bergabung dalam komunitas yang mendukung pemberian ASI dengan tujuan mendapatkan informasi yang akurat. Komunitas dapat diakses dengan menggunakan TIK seperti FB AIMI. FB AIMI memberikan informan pengetahuan, dukungan serta meningkatkan motivasi dalam penerapan manajemen ASI agar tetap konsisten. Dampak positif yang dirasakan dari penerapan manajemen ASI mendorong informan untuk menyebarluaskan manajemen ASI kepada masyarakat. TIK berperan menyebarluaskan manfaat yang telah dirasakan oleh informan.

TIK memberikan kontribusi terhadap keadaan sumberdaya fisik menjadi lebih baik. Kontribusi tersebut memberikan pengaruh terhadap masalah fisik keluarga dalam penerapan manajemen ASI menjadi rendah. TIK diberdayakan dalam penanggulangan masalah fisik keluarga sehingga mendorong kesejahteraan fisik semakin baik. Semakin baik penanggulangan masalah fisik keluarga maka ketahanan fisik keluarga dalam manajemen ASI tercapai.

Motivasi yang diperoleh melalui FB AIMI berkontribusi terhadap pemecahan masalah keluarga non fisik maka ketahanan psikologi keluarga dalam manajemen ASI dapat tercapai. Sumberdaya non fisik berupa dukungan keluarga inti dan keluarga besar merupakan hasil edukasi yang benar memberikan kontribusi terhadap tercapainya ketahanan sosial. Apabila ketiga komponen tersebut tercapai maka ketahanan keluarga dalam manajemen ASI berkat penggunaan teknologi pun tercapai.

Menurut Sunarti (2003), kualitas SDM yang baik merupakan prasyarat untuk mencapai ketahanan fisik yang merupakan komponen dari ketahanan keluarga. Kepercayaan diri ibu bekerja terhadap informasi manajemen ASI yang benar akan mendorong penerapan manajemen ASI. Salah satu tujuan penerapan manajemen ASI yaitu menjamin keluarga memiliki kualitas SDM yang baik. Keluarga merupakan bagian terkecil dari masyarakat maka ketahanan keluarga mendukung dalam peningkatan ketahanan lingkungan. Ketahanan lingkungan yang tinggi kemudian akan membentuk ketahanan masyarakat sehingga pada akhirnya meningkatkan ketahanan nasional (Juzak, 1997).

\section{SIMPULAN}

Berdasar penjelasan tersebut di atas dapat ditarik simpulan sebagai berikut.

Pertama, informasi yang diperoleh hasil penggunaan TIK hanya dapat dianggap sebagai informasi pendukung karena pengguna komputer harus memiliki kemampuan dan kompetensi dalam memilah informasi. TIK sebagai alat untuk mendapatkan informasi pendukung tentang manajemen ASI melalui internet sebagai bahan edukasi keluarga selama informasi tersebut dapat dipertanggungjawabkan. Informasi utama mengenai manajemen ASI diperoleh melalui konsultasi atau pelatihan dengan narasumber 
laktasi dan referensi dari buku-buku terkait. TIK merupakan faktor pendukung dalam penerapan manajemen ASI menjadi bagian ketahanan fisik untuk mendukung ketahanan keluarga. Penggunaan TIK sangat membantu dalam proses memperoleh informasi mengenai manajemen ASI. TIK digunakan untuk memperoleh pengetahuan mengenai manajemen ASI yang akurat agar dapat diterapkan.

Kedua, berdasarkan model proses pencarian informasi menurut Kuhlthau, penggunaan TIK berkontribusi dalam mempersingkat waktu pada tahap seleksi atau identifikasi topik. Tahap penjelajahan didukung oleh penggunaan TIK melalui penggunaan sosial media untuk melakukan diskusi. Pada tahap perumusan, penggunaan TIK membantu informan untuk menentukan topik informasi yang lebih personal. Penggunaan TIK berkontribusi dalam sumber daya non fisik dengan membantu informan memperoleh informasi manajemen ASI serta meningkatkan pengalaman dan kemampuan informan dalam mencari informasi di dunia maya, serta berkontribusi dalam penanganan masalah keluarga non fisik dalam bentuk dukungan sosial yang butuhkan informan agar tetap konsisten menerapkan manajemen ASI. Dukungan yang meningkatkan motivasi diperoleh informan baik dari keluarga maupun melalui FB AIMI.

Ketiga, penggunaan TIKdalammanajemen ASI bagi ibu bekerja memberikan kontribusi dalam menjaga ketahanan keluarga. Output yang ingin dicapai yaitu memperoleh kualitas SDM yang baik sebagai prasyarat ketahanan fisik dalam ketahanan keluarga. Informan menerapkan manajemen ASI apabila merasa percaya diri terhadap informasi yang dimiliki. Pengalaman dari hasil penerapan informasi mengenai manajemen ASI kemudian dibagikan kepada masyarakat melalui media sosial.

Keempat, FB AIMI sebagai komunitas yang mendukung pemberian ASI perlu terus berusaha untuk melakukan sosialisasi dan mengedukasi masyarakat melalui media sosial agar manajemen ASI sedini mungkin diketahui bagi calon ibu dan ibu menyusui. Mengantisipasi kendala anggota FB AIMI dalam menyaring informasi yang benar dan valid maka disarankan agar menjaga informasi akurat dan terkini untuk menyesuaikan perkembangan jaman karena informasi yang tersedia seringkali dijadikan referensi dasar dan acuan dalam manajemen ASI terutama bagi anggota di daerah yang terbatas narasumber laktasi.

\section{DAFTAR PUSTAKA}

Bell, G., 2006. "Satu Keluarga, Satu Komputer (One Home, One Computer): Cultural Accounts of ICTs in South and Southeast Asia”. Design Issues. Cambridge: Massachusetts Institute of Technology.

Fahriani, R. Rinawati, R. Aryono, H. 2014. "Faktor yang Memengaruhi Pemberian ASI Ekslusif pada Bayi Cukup Bulan yang Dilakukan Inisiasi Menyusui Dini (IMD)”. Sari Pediatri. Jakarta: Ikatan Dokter Anak Indonesia.

Fikawati, S. Ahmad, S. 2010. "Kajian Implementasi Dan Kebijakan Air Susu Ibu Eksklusif Dan Inisiasi Menyusu Dini Di Indonesia.” Makara Seri Kesehatan. Depok: Universitas Indonesia.

Hastuti, W. 2014. “Faktor- Faktor Yang Berhubungan Dengan Pemberian Air Susu Ibu Eksklusif (0-6 Bulan) Di Kota Semarang”. Tesis. Yogyakarta: S2 Magister Keperawatan UGM. 
Valentina Siwi Saridewi, Armaidy Armawi, dan Djoko Soerjo -- Penggunaan Teknologi Informasi Komunikasi Dalam Manajemen ASI Bagi Ibu Bekerja Guna Menjaga Ketahanan Keluarga (Studi Pada Anggota Grup Facebook Asosiasi Ibu Menyusui Indonesia)

Juzak, S.S. 1997. "Peranan Keluarga Sejahtera Dalam Meningkatkan Ketahanan Nasional Studi Kasus Keluarga Sejahtera Di Kota Administratif Depok.” Tesis, Depok: Program Pascasarjana Universitas Indonesia.

Laksono, A. D. Ratna, D. W. 2011, “Analisis Potensi Penyebaran Informasi Kesehatan Melalui Jejaring Sosial (Studi Kasus Pada 'Forum Jejaring Peduli AIDS')”. Buletin Penelitian Sistem Kesehatan. Surabaya: Pusat Penelitian dan Pengembangan Sistem dan Kebijakan Kesehatan.

Melasari, I. 2014. “Pengalaman Ibu Mendapatkan Informasi Menyusui Melalui Media Sosial”. Tesis, Depok: Program Magister Ilmu Keperawatan Kekhususan Keperawatan Maternitas Universitas Indonesia.

Novrida, H.S. 1997. “Kontribusi Pekerja Wanita Dalam Kehidupan Keluarga Guna Menunjang Ketahanan Keluarga Dan Ketahanan Nasional (Studi Kasus Di Perkebunann Teh, Industri Pakaian Jadi Dan Pasar Swalayan).” Tesis. Depok: Program Magister Pascasarjana Universitas Indonesia.

Oswari, T. Euphrasia, S. S. Ati, H. 2008. "Model Perilaku Penerimaan Teknologi Informasi: Pengaruh Variabel Prediktor, Moderating Effect, Dampak Penggunaan Teknologi Informasi Terhadap Produktivitas dan Kinerja Usaha Kecil”. Proceeding Seminar Ilmiah Nasional Komputer dan Sistem Intelijen (KOMMIT 2008). Jakarta: Universitas Gunadarma.

Sunarti, E. Syarief, H. Ratna, M. Hardinsyah. Asep, S. Husaini. 2003. "Perumusan Ukuran Ketahanan Keluarga”. Media Gizi \& Keluarga. Bogor: Institut Pertanian Bogor. Suradi, R.. 2001. "Spesifitas Biologis Air Susu Ibu. Sari Pediatri.” Jakarta: Ikatan Dokter Anak Indonesia.
Syafiq, A. 2007. “Tinjauan Atas Kesehatan Dan Gizi Anak Usia Dini”. Diskusi Peningkatan Kesehatan dan Gizi Anak Usia Dini. Jakarta: Bappenas.

Triratnawati, A. 2003. "Aspek Simbolisme Telepon Genggam”. Humaniora. Yogyakarta: Universitas Gadjah Mada

Venkatesh, V. Michael, G. M. Gordon, B. D. Fred D. D, 2003. "User Acceptance of Information Technology: Toward a Unified View.” MIS Quarterly. Minneapolis: University of Minnesota.

Wibowo, M. 2014. "Hambatan Pemberian Air Susu Ibu Eksklusif di Kecamatan Gondokusuman Kota Yogyakarta Daerah Istimewa Yogyakarta”. Tesis. Yogyakarta: S2 Ilmu Kesehatan Masyarakat UGM.

Wuryanta, A.G.E.W. 2013. “Digitalisasi Masyarakat: Menilik Kekuatan dan Kelemahan Dinamika Era Informasi Digital dan Masyarakat Informasi”. Jurnal Ilmu Komunikasi. Yogyakarta: Universitas Atma Jaya Yogyakarta.

Yani, I. E. Defriani, D. Novelasari. 2009. “Faktor-Faktor Yang Mempengaruhi Perilaku Ibu Laktasi Dalam Memberikan ASI Di 6 Kabupaten/Kota Di Provinsi Sumatera.” Penelitian Gizi dan Makanan. Bogor: Kementerian Kesehatan Republik Indonesia.

\section{Peraturan Perundangan}

Undang-Undang Republik Indonesia Nomor 13 Tahun 2003 Tentang Ketenagakerjaan.

\section{Internet}

Kuhlthau,C.C.2015.http://comminfo.rutgers. edu/ kuhlthau/information_search_ process.htm 